\title{
Monthly Reports on the Fishing in the Neighbourhood of Plymouth.
}

\author{
By \\ w. L. Calderwood, \\ Director of the Laboratory of the Marine Biological Association.
}

II.

The four charts published in this number, being for the months of May, June, July, and August, form a continuation of the series of reports commenced in the last number (vol. ii, No. 3) and are intended to show the position of the fishing fleets.

The same symbols have been used, which, for convenience, are again given below.

I do not propose to attempt a full description of each month's fishing, but rather let the charts explain themselves, giving only a few necessary notes on the dates of the movements of shoals, which may be of use on a subsequent occasion.

May.-The mackerel fishing marked on this chart only lasted till the 7 th of the month. The shoals were travelling rapidly towards the westward, and on the 10th were found 20 miles south-west of the Eddystone. On the 14th all the fleet left Plymouth and proceeded to St. Ives, from which port large catches were obtained.

The whiting fishing was very poor, and the boats changed ground so frequently that a proper estimate of their position became difficult.

The majority of trawlers worked much more to the westward than can be shown on the chart, the positions shown being only taken up on the dates placed against them.

The pilchard fishing marked in Whitsand Bay occurred on the 22nd inst.

June.-The mackerel are in this chart marked as being close inshore, and extending from the Mewstone to the Eddystone. The fish occurred in this position for only a short time about the 10th; 


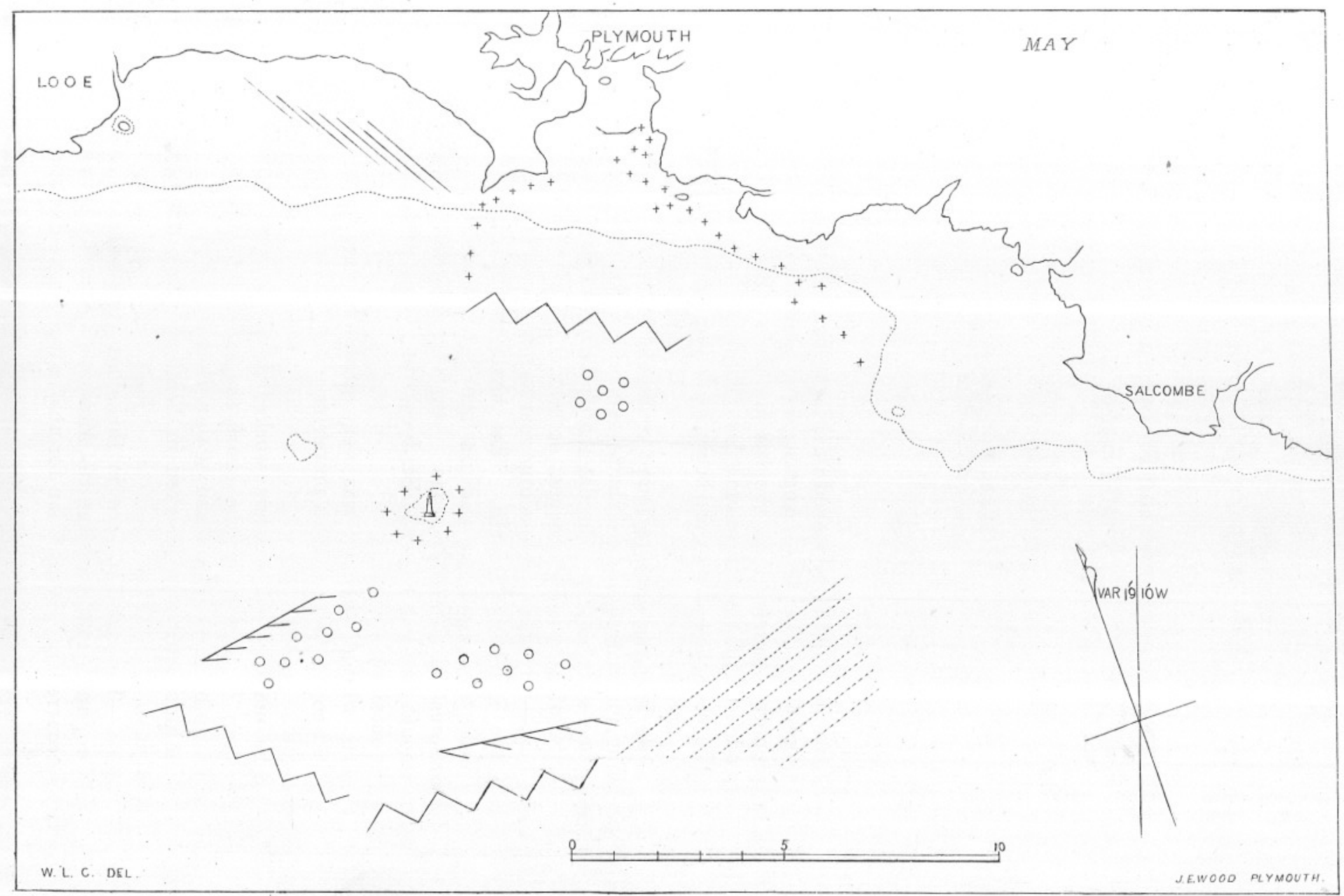




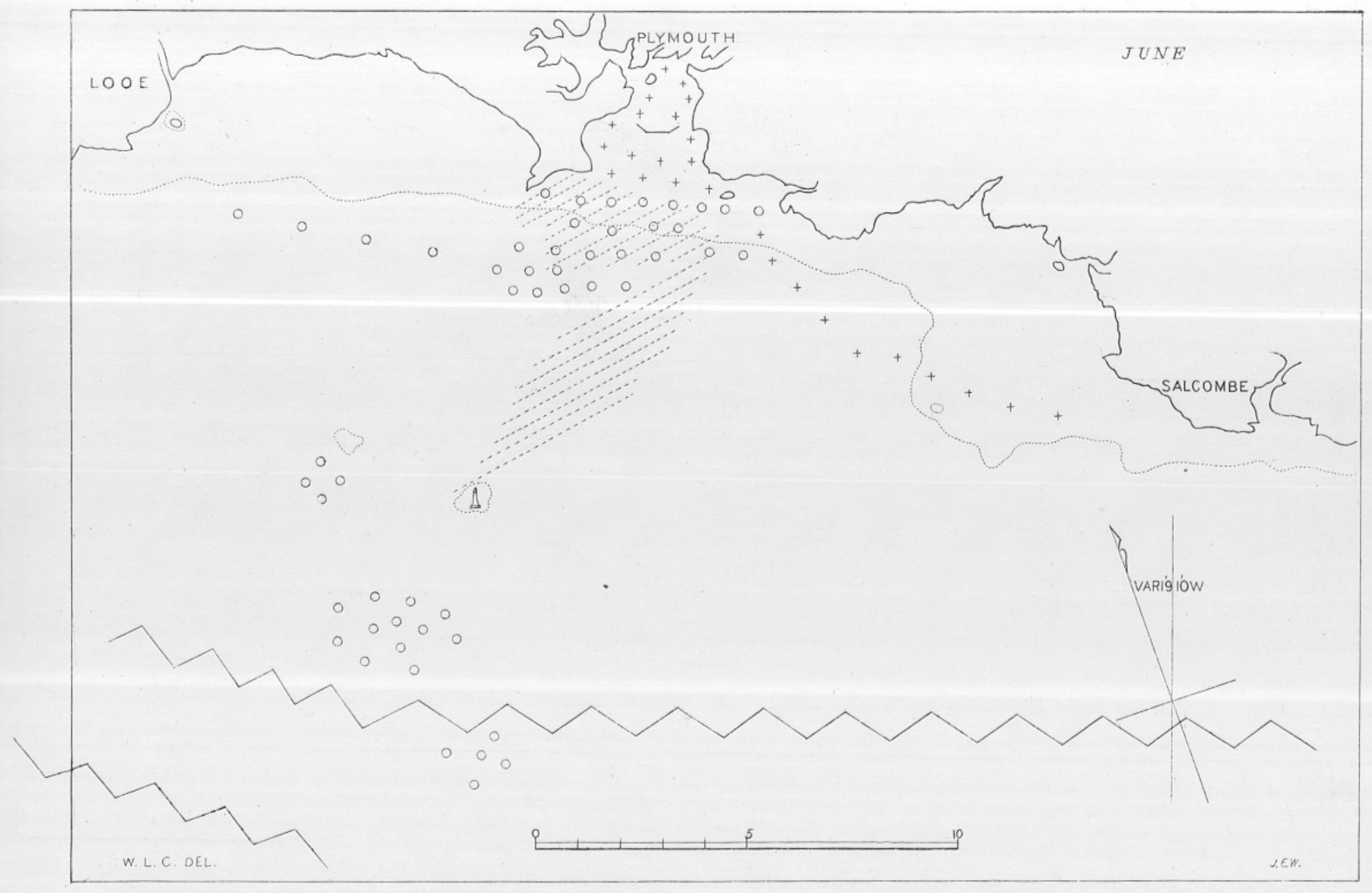




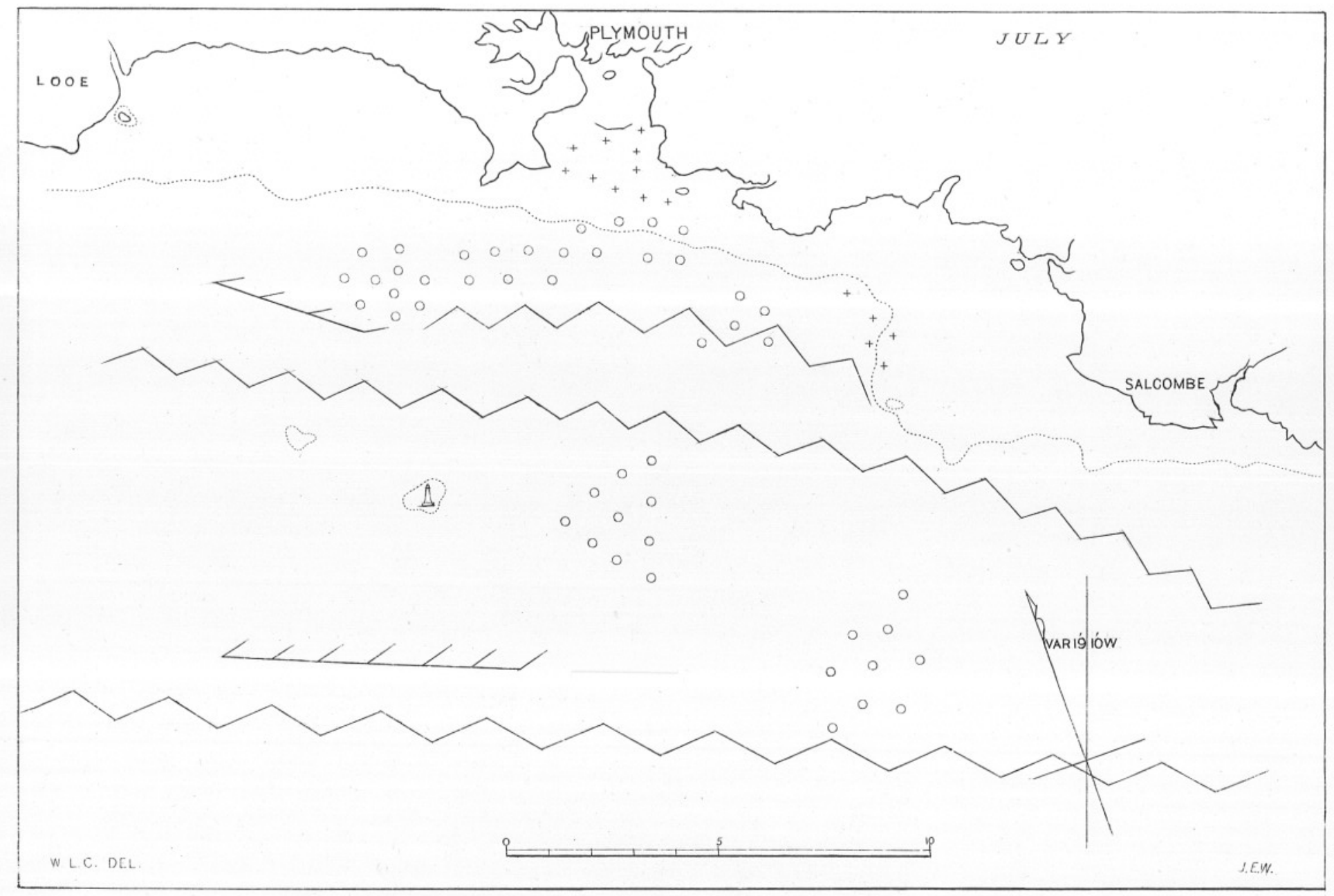




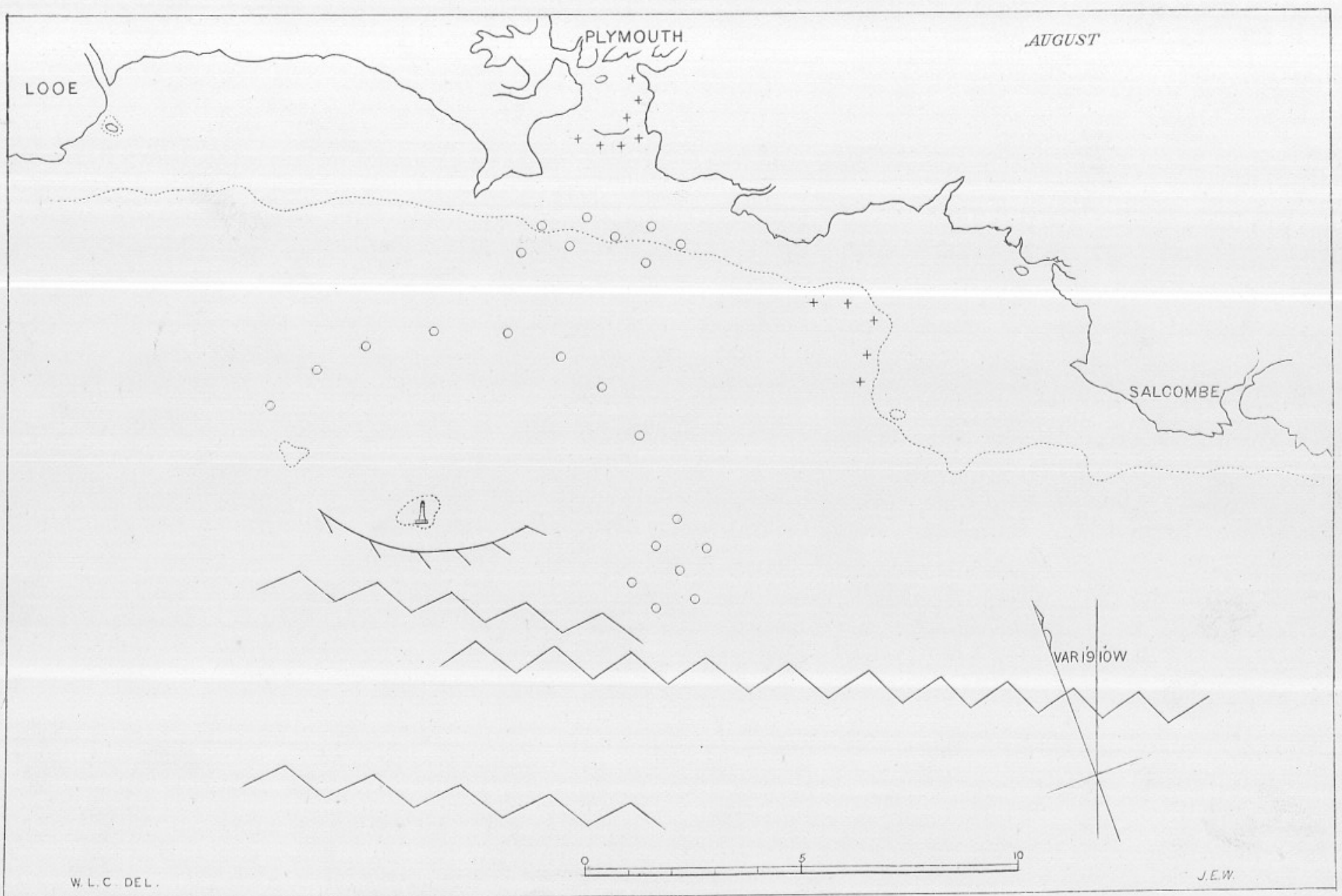


the majority of the boats were fishing 40,60 , and 70 miles south and west of the Eddystone. A large number of the whiting boats, on account of their ill-luck, took to mackerel fishing. The longliners are not marked. Only one boat was at work from 10 to 25 miles south-west of Eddystone.

July.-The mackerel boats are still far south of Eddystone (35 to 75 miles).

The whiting boats are still a good deal scattered, and more trawlers are working in the area included by the charts.

All trawlers not working on the "home grounds" (about half the fleet) are fishing the Bristol Channel.

Long-liners, besides those marked on the chart, are at work 10 to 20 miles south of Eddystone.

August.-The long-liners marked here just south of the Eddystone occupied this ground only during the last week of the month. During the early part they were fishing off Bolt Head and Prawl Point.

The mackerel fishing is now drawing to a close, the fish going further and further south. By the middle of the month they were captured from 60 to 70 miles south of Eddystone, some of the boats being within sight of the French lights. By the 20th the fishing ceased for the season. Trawlers still working largely on the " home grounds."

Key to Symbols used in Monthly Fishery Charts.

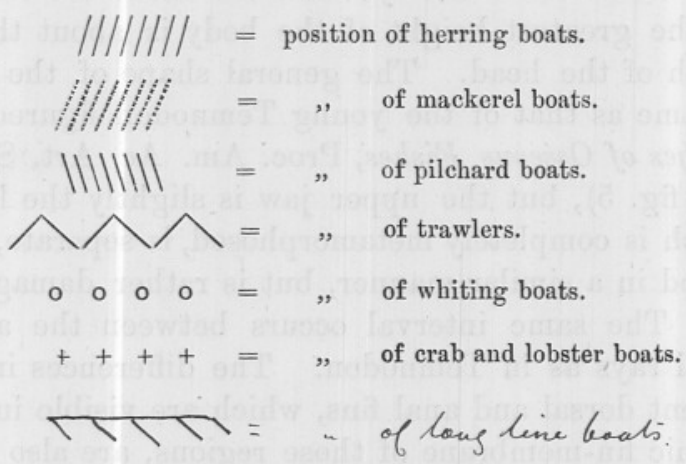

